\title{
Imperial Frontier in the World Outlook of the Decembrists. A. A. Bestuzhev-Marlinsky: a Romantic Historiosophy and Expansion into the Caucasus
}

\section{Vladimir N. Smirnov}

St. Petersburg State University. St. Petersburg, Russia. Email: pustota94[at]yandex.ru

\section{Abstract}

The historiography of Russian expansion into the Caucasus is very extensive and continues to be replenished with new research, since this topic will hardly ever be exhausted and interest in it is unlikely to dwindle. The same can be said about the Decembrist uprising and the subsequent fate of those rebels who were sent into exile to various parts of the Russian Empire. The frontier theory makes it possible to link these two topics both by taking a fresh look at some of the most wellknown subjects in Russian history and opening up new lines of research in traditional frontier studies. The purpose of this study was to conduct a historical and philosophical analysis of the literary heritage of the Decembrist A. A. Bestuzhev-Marlinsky in order to reconstruct his worldview through the lense of frontierism. A. A. Bestuzhev-Marlinsky's literary pieces, philosophical theses, military notes and personal letters were analyzed in connection with his existential experience of the Caucasian War and historical events to which he bore witness. Conclusions are drawn, regarding various aspects of his worldviews, some of which remained unshakable, whereas others were transformed under the influence of the frontier. Due to its interdisciplinary nature, this article may be of interest to the historians who study both Russian development of the Caucasus and Russian social thought of the 19th century.

\section{Keywords}

Decembrists; Empire; Loyalty; Caucasus; Romanticism; Historiosophy; Orientalism; A. A. BestuzhevMarlinsky; Ghazi Muhammad; Caucasian War

This work is licensed under a Creative Commons "Attribution" 4.0 International License 


\section{Имперский фронтир в мировоззрении декабристов. А.А. Бестужев-Марлинский: романтическая историософия и экспансия на Кавказ}

\section{Смирнов Владимир Николаевич}

Санкт-Петербургский государственный университет. Санкт-Петербург, Россия. Email: pustota94[at]yandex.ru

\section{Аннотация}

Историография российской экспансии на Кавказ весьма обширна и продолжает пополняться новыми трудами, поскольку данная тема едва ли когда-нибудь будет исчерпана и интерес к ней пропадет. То же самое можно сказать относительно темы восстания декабристов и их последующей судьбы в ссылке в различных концах Российской империи. Фронтирная теория позволяет связать две эти темы, с одной стороны, дав новую оптику хорошо известным сюжетам российской истории, с другой стороны, взяв свежий материал для традиционных фронтирных исследований. Нашей целью было провести историко-философский анализ литературного наследия декабриста А.А. Бестужева-Марлинского с тем, чтобы реконструировать его мировоззрение через призму фронтирной тематики. В ходе анализа были проанализированы художественные произведения, философские работы, военные записки, эпистолярное наследие А.А. Бестужева-Марлинского в связи с его экзистенциальным опытом Кавказской войны и историческими событиями, участником которых он стал. Сделаны выводы относительно различных сторон его мировоззрения, одни из которых остались незыблемы, а другие трансформировались под влиянием фронтира. Ввиду междисциплинарного характера, статья может быть интересна как исследователям истории российского освоения Кавказа, так и историкам русской общественной мысли XIX века.

\section{Ключевые слова}

декабристы; империя; лояльность; Кавказ; романтизм; историософия; ориентализм;

А. А. Бестужев-Марлинский; Кази-Мулла; Кавказская война

Это произведение доступно по лицензии Creative Commons “Attribution” («Атрибуция») 4.0 


\section{Введение}

Обращение к фронтирной теории для изучения истории Российской империи в целом и отдельных регионов, входящих в состав наступающей империи, несмотря на определенную критику, остается весьма полезным и многообещающим методологическим инструментом. Настоящее исследование проводится не столько в историческом, сколько в историко-философском ключе и тяготеет к такому направлению как интеллектуальная история. Сама концепция фронтира и характерная терминология представляется подходящей для всевозможных междисциплинарных изысканийํ. Таким образом, в настоящем исследовании предпринимается попытка применения фронтирной теории к истории идей через историю интеллектуалов.

Восстание декабристов и дальнейший судебный процесс стали, по сути, началом декабристского влияния на российскую историю и интеллектуальную культуру, когда бывшие участники декабристского движения оказались разметаны по разным концам Российской империи. Ссыльные имели весьма сложные, подчас противоречивые взгляды на империю как систему и на принципы взаимоотношений с народами, попадающими в орбиту влияния расширяющегося государства. Так или иначе, передовые, европейски воспитанные люди стали важными агентами имперской цивилизаторской миссии, которая подчас ими же и формулировалась.

Одним из направлений декабристских скитаний оказался Кавказ. Декабристы существенным образом повлияли не только на интеллектуальный ландшафт своей эпохи, но и на культуру последующих десятилетий. И даже далее. Многие стремятся видеть в них своих «союзников в истории». По этой причине их наследие неизменно вызывает интерес и актуализируется. То же самое можно сказать и про историю покорения Кавказа, которая зачастую связывается с актуальными на момент исследования событиями.

Т.М. Баррет в статье «Линии неопределённости: северокавказский “фронтир" России» предостерегает от однозначных интерпретаций истории расширения Российской империи и призывает не упрощать общую картину российского продвижения на Кавказ, которое не сводится к завоеванию и колониальному насилию. Он вносит ряд поправок в набирающую на тот момент популярность интерпретацию Кавказа через классическую фронтирную оптику Ф.Дж. Тернера и указывает на те места, где американский фронтир коренным образом отличался от имперских окраин (Барретт, 2000).

Применение фронтирной теории к истории русской экспансии на Кавказ представляется целесообразным, поскольку еще классическая работа Тернера, описывающая американский фронтир, предлагает целый ряд тем, рифмующихся с историей российского освоения Кавказа. К основным таким темам относятся: противостояние «дикости» и «цивилизации», взаимоотношение

1 См. подробно: (Синельникова, 2020). 
фронтирных жителей с государственной властью, межэтническое взаимодействие, трансформация личности в условиях фронтира. Последней теме посвящена популярная монография М. Ходарковского «Горький выбор. Верность и предательство в эпоху российского завоевания Северного Кавказа». В ней через микрокроисторическое повествование о судьбе русского казачьего офицера кавказского происхождения передается противоречивое мироощущение жителей южного фронтира на фоне российской экспансии на Кавказ (Ходарковский, 2016).

Особый интерес представляет статья О. Джерсильда «Ориентализм и империя: северокавказские горцы и грузинский фронтир, 1845-1917» (Jersild, 2002). В ней дается объемное описание истории Российского продвижения на Кавказ и уделяется внимание также истории идей, что наиболее важно для настоящей работы.

Все это дает основания активно применять фронтирную теорию при исследовании Кавказа и в отечественной литературе (Баева, 2014; Романова, Ермуханова, 2015). Сам Тернер пишет: «Понимание фронтирного взаимодействия, в широком смысле слова, стало означать контакт (с последующими взаимными реакциями) носителей языков, идей (религий), технологий, типов хозяйствования» (Тернер, 2009). Именно этот контакт и взаимовлияние европейской культуры и культуры окраинных народов вызывает наибольший интерес для изучения жизни и интеллектуального наследия декабристов, оказавшихся на границе расширяющейся империи. Особого внимания заслуживает вопрос столкновения европейских просвещенческих представлений и романтических идей о «народном духе» с реальным этнографическим опытом.

Таким образом, нашей основной методологической установкой будет сопряжение фронтирной тематики и интеллектуальной истории. С одной стороны, речь идет об истории идей, воплотившейся в истории интеллектуалов, которые оказались в условиях фронтира, там, где имеет смысл периодическая смена фокуса между микро- и макроуровнем исторической оптики. С другой стороны, фронтир интерпретируется нами не только в пространственном измерении, но и в экзистенциальном, где оптика направляется на внутренние сближения и конфронтации в мировоззрении интеллектуала. Необходимо высветить взаимосвязь этих двух измерений.

\section{Империя и декабристы}

Другим основанием применения фронтирной теории к истории Российской империи является сходство исторических судеб России и Соединенных Штатов Америки, которое бросалось в глаза человеку XIX века. Для русской общественной мысли того времени весьма характерно сравнение России с молодым американским государством: «Взгляните, например, на эти две огромные равнины, которые соприкасаются затылками, обогнув Европу. 
Зачем они так пространны, к чему они готовятся, что означает пожирающая их страсть к деятельности, к расширению? Эти два мира, столь противоположные и все же в чем-то схожие, - это Соединенные Штаты и Россия», - писал Герцен (цит. по Валицкий, 2013, с. 183). На это обратил внимание и Токвиль (Валицкий, 2013, с. 183). Обе страны воспринимаются как молодые наследники европейской культуры, которым суждено сказать свое особое слово в истории. Вобрав в себя весь исторический опыт, всю образованность старой Европы, молодые народы должны сделать следующий шаг в развитии человечества. Под «человечеством» здесь конечно понимается Европейская иивилизация, а «шаг» может трактоваться как перемещение в пространстве. Впрочем, в русской общественной мысли речь шла преимущественно о нравственном влиянии, о распространении идей, а не буквальной колониальной экспансии, которая воспринималась лишь как инструмент. И славянофилы (Койре, 2003, с. 223), и западники (Валицкий, 2013, с. 183) сходились на том, что ведущую роль предстоит сыграть именно России, поскольку Америка содержит в себе дух старой протестантской Европы, но она не переставала привлекать внимание как параллельно развивающийся эксперимент.

По образцу Соединенных Штатов Америки хотел преобразовать Россию главный идеолог Северного общества Никита Муравьев. Его конституция предполагала федеративное деление на 13 держав, одной из которых была бы Кавказская со столицей в Тифлисе (Муравьев, 1951, с. 304). «Русская правда» идеолога Южного общества Пестеля отличалась значительно большим этатизмом и централизмом, предполагала ряд жестких колониальных мер по отношению к народам Кавказа. Кавказцы здесь не получают самоуправления, разделяются на «буйных» и «мирных». Первым позволяется остаться на своей земле, вторые насильственно переселяются в другие части империи. Освободившиеся земли планируется заселить русскими колонистами (Пестель, 1958). Проект Пестеля тяготеет к политическому реализму: служа в Бессарабии, он сам был фронтирным офицером, хорошо представлял государственные интересы на Юге Империи и не мог принести их в жертву абстрактным гуманистическим идеалам.

Идеология декабризма не была сформулирована в качестве хоть скольконибудь последовательной концепции. Не существовало и конвенционального мнения по ключевым вопросам у участников движения даже в рамках того или иного общества. Северное общество, к которому относился Александр Александрович Бестужев-Марлинский, тяготело к традиции аристократического либерализма, возникшего еще в Екатерининскую эпоху. Характерной чертой здесь являлась либерально-националистическая идеализация русской старины и отчасти приписываемых ей феодальных свобод. Этот мотив присутствует в публицистике Марлинского, появившийся уже после восстания и следствия. Нужно отметить, что отличительной чертой братьев Бестужевых было однозначно положительное отношение $\kappa$ фигуре Петра І. Политическим 
идеалом Марлинского была монархия, сопряженная с влиянием аристократии. Представляется, что в своих поздних записках Бестужев-Марлинский был искренен в подчеркнутой лояльности государю и империи: «Я уверен, что Небо даровало в Вас другого Петра Великого... более чем Петра, ибо в наш век и с Вашими способностями, Государь, быть им - мало», - пишет он Николаю I (Бестужев-Марлинский, 1981с, с. 493).

В своих политических устремлениях и программных текстах декабристы ориентировались на французскую и английскую социальную мысль, связанную с культурой Просвещения. Не был исключением и Марлинский, который прямо на следствии объявил, что мятежные мысли в нем возникли под влиянием французских, английских публицистов (прежде всего Бентама) (Следственное дело, 1925, с. 430). Между тем, интерес к французской мысли в русском обществе постепенно угасал. А. Койре писал что, декабристский мятеж можно считать датой окончания французского влияния (Койре, 2003, c. 27). На смену Просвещению пришел Романтизм, просвещенческий космополитизм сменился ролантическил национализмол, основывающимся на различных историософских концепциях. Это пограничье между эпохами и парадигмами интеллектуальной культуры отчетливо ощущается в мировоззрении многих участников декабристского движения.

\section{Романтическая теория и фронтирная эмпирика}

В статье «Взгляд на русскую словесность в течение 1823 года» Бестужев пишет об отсутствии в России национальной литературы, о том, что, победив Наполеона, русское общество продолжает ориентироваться на французские образцы. Он хвалит две книги - «Новейшие известия о Кавказе» С. Броневского и «Путешествие по Тавриде» И. Муравьева-Апостола. Они, с его точки зрения, содержат ценные исторические и географические сведения (БестужевМарлинский, 1981a). Такие же мысли высказывались им во «Взгляде на русскую словесность в течение 1824 года» (Бестужев-Марлинский, 1981b). Романтизм у Марлинского - это «стремление бесконечного духа человеческого выразиться в конечных формах» (Бестужев-Марлинский, 1991, с. 137). В романтическом мировоззрении всемирное раскрывается через национальное, при этом ценность народов определяется великими историческими событиями, отраженными в искусстве. XIX век объявляется веком романтизма, историческим веком, этим и обусловлена необходимость создавать национальную литературу. Его романтическая теория возникла до восстания и развивалась им уже после следствия, во время пребывания на Кавказе, обогащаясь фронтирным опытом, приобретала ориентальные черты.

Понятия «Азия» и «азиатчина» имеют двоякое значение в мировоззрении Бестужева. С одной стороны, это категории, обозначающие нечто чуждое, «противоположное», с другой - под «азиатчиной» порой читается метафори- 
ческое изображение некоторых сторон русской жизни - отдающее чаадаевской горечью. В одном из дагестанских писем он замечает: «Трудно себе вообразить, как легко взбунтовать азиатцев! Самые нелепые слухи, самые невероятные надежды, самые несбыточные обеты идут у них за чистое золото. И что мудреного! Люди, для которых нет ни вчера, ни завтра и оттого ни опытности за минувшее, ни расчета на будущее; люди, которые не видят и в настоящем того, что есть и как оно есть, а того менее, как оно быть должно; люди, которым Бог дал довольно ума, но обстоятельства не развернули нисколько разума, очень легко меняют верное на неверное, более любят ружье, чем заступ, и охотнее переносят нужду, чем труд» (Бестужев-Марлинский, 1995d, с. 96). Именно неукорененность русских в истории будет основным мотивом пессимистических взглядов Чаадаева на Россию.

В основе взглядов как Бестужева, так и Чаадаева лежали романтические историософские воззрения, где каждый народ должен сказать свое слово в общем развитии человечества, но для этого он, конечно, должен жить исторической жизнью и иметь представления о себе в прошлом и будущем ${ }^{1}$. Завоевать для себя прошлое и будущее, России предстоит, по мысли Марлинского, через становление национальной литературы, в которой воспроизводятся сюжеты подлинной российской истории. В отношении к самой истории России Бестужев стоял на позиции противоположной чаадаевской:

«Русь была отчуждена от Европы, не от человечества. За исключением крестовых походов и реформации, чего у нас не было, что было в Европе? А сверх того, характеры князей и народа долженствовали у нас быть ярче, самобытнее, решительнее, потому что человек на Руси боролся с природою более жестокою, со врагами более ужасными, чем где-либо» (Бестужев-Марлинский, 1991, c. 172).

Другой азиатской чертой в России мыслитель называл склонность к бунту ради несбыточных, фантастических целей. Часть исследователей утверждают, что Марлинский после восстания и следствия оставался убежденным бунтарем и лишь изображал лояльность государю. Но это не кажется убедительным мнением. Свое собственное участие в тайном обществе он объяснял буйным воображением, молодостью и «приманкой новизны и тайны» (Следственное дело, 1925, с. 431). Горцев, против которых он действует в составе русской армии, Марлинский постоянно называет «мятежниками», которых соответственно нужно усмирить на благо русской империи и во славу русского императора. Россия, с его точки зрения, сама вырванная волей Петра Великого из среды азиатских царств, несет цивилизаторскую миссию на благо всего человечества. Российская экспансия обосновывается благом человечества, а не узконациональным эгоизмом:

«Не пустые завоевания, но победа над варварством, но благо человечества были его целию. Дербент, Бака, Астрабат - вот звенья цепи, которою хотел он опутать

1 См. подробно: (Смирнов \& Евлампиев, 2020). 
Кавказ и связать торговлю Индии с русскою. Полубог Севера! Ты, которого создала природа, чтобы польстить гордости человека и привести в отчаяние недоступным величием, - твоя тень возникла передо мной, огромна и лучезарна, и водопад веков, казалось, рассыпался в пену у твоих стоп» (БестужевМарлинский, 1995a, с. 56).

Примечательно, что у декабриста Н.А. Бестужева также было крайне восторженное отношение к фигуре Петра Великого и его деяниям, что в целом не очень характерно для декабристского движения (Андреева, 2021, с. 74).

Необходимо заметить, что Бестужев-Марлинский в своих развернутых суждениях выносит весьма разные оценки тем народностям, с которыми сталкивается на Кавказе:

«Я не смешиваю, впрочем, горцев с плоскими жителями плоскостей. Горцы уже своею зимой придвинуты к европеизму; они всегда были и будут умнее и воинственнее жильцов долин. Но все-таки они не более как умные ребятишки. В сердце Кавказа есть, однако ж, племена, которые никогда не сходились с русскими, хотя живут недалеко от границ. Как любопытно бы видеть этих китайцев горских! Вообще Кавказ вовсе неизвестен: его запачкали чернилами, выкрасили как будку; но попыток узнать его не было до сих пор, или люди, на то назначенные, не имели средств, познаний, отваги, случая. Особенно мы худо знаем Чечню» (Бестужев-Марлинский, 1995g, с. 520).

Призыв к тому, чтобы начать узнавать Кавказ, пытаться понять его, наверное, является важнейшей интенцией творчества Марлинского. По-своему парадоксально, что именно Марлинский сыграл ведущую роль в романтизации Кавказа (на что обратил внимание, например, Л.Н. Толстой (Толстой, 1979, с. 14) и восприятии его в оптике европейского романтического ориентализма. В письме к родственникам 1830 года Александр Бестужев пишет о желании изучить татарский язык, для чего требуется учебник татарской грамматики (Бестужев-Марлинский, 1995k, с. 491). Уже в одной из дагестанских заметок 1831 года он сообщает: «Меня очень любят татары за то, что я не чуждаюсь их обычаев, говорю их языком, и потому каждый раз, когда я выходил на стены подразнить и побранить врагов, прогуливаясь с трубкою в зубах, куча дербентцев окружала меня...» (Бестужев-Марлинский, 1995d, с. 105). Язык у Марлинского имеет характерное для романтического мировоззрения значение отражения народного духа и народной истории (БестужевМарлинский, 1995n, с. 174). Этнографические изыскания Марлинского оценивались по-разному, но он бесспорно имеет право на свою, подчас противоречивую, картину Кавказской жизни.

В одном из писем к брату, Павлу Бестужеву, принимавшему участие в Персидской и Турецкой кампаниях, Марлинский призывает его пристально наблюдать нравы «диких народов» и видеть за их дикостью некий человеческий субстрат, явленный в первобытной незамутненности. Заметив этот человеческий субстрат в «дикаре», можно лучше узнать и сущность светских людей, скрытую внешней образованностью (Бестужев-Марлинский, 1981d). 
Здесь хорошо видно, как концепт «благородного дикаря» соприкасается с эмпирическим этнографическим материалом.

Интенции Марлинского осознанно или неосознанно соответствовали насущным потребностям имперского строительства на Кавказе. Дело в том, что вхождению Кавказа в орбиту влияния русской государственности мешало малое количество чиновников, способных к административной работе в условиях фронтира. Одной из главных проблем было практически полное отсутствие сотрудников, способных изъясняться на местных языках. Даже те, кто имел местное этническое происхождение, оказывались в затруднительной ситуации. Российская администрация, стремясь переломить сложившееся положение, ввела изучение татарского языка в Тифлисском училище. Полиэтничность в кавказском учебном заведении отвечала двум основным задачам формированию имперской администрации, знакомой со спецификой региона, и имперской социализации автохтонного населения, которое приобщаясь к русской культуре в значительной степени сохраняло свои традиции и образ жизни (Хлынина и др., 2012, с. 46-64). Решение этих задач обеспечивало появление необходимого для империи типа фронтирных людей - лояльных горцев и русских офицеров, чиновников, связавших свою жизнь со службой на Кавказе.

Петр Бестужев, как и его брат Павел, принимал участие в Персидской и Турецкой кампаниях. Он оказался на Востоке не по своей воле и сильнее тяготился своим фронтирным опытом. Его наблюдения в большей степени отражают опыт европейца, соприкоснувшегося с чуждой культурой. Наблюдения за восточными культурами ассоциируются у него с европейскими представлениями о государстве и обществе, характерными для его времени и тем кругом проблем, который обсуждался в то время передовой европейской публикой. Рассуждая о персидском обществе, он пишет:

«Современные нам персы - живой пример унижения всех восточных монархий - есть не что иное, как тень гражданского общества, составленного из рабов хитрых, корыстолюбивых, без малейшего признака народной гордости, с мелкою продажною душою, сластолюбивых в грубой чувственности; невежд даже в отношении к азиатской роскоши, воспеваемой поэтами и превозносимой путешественниками» (Бестужев, 1951, с. 351).

Понятно, что понятия «гражданское общество» и «народная гордость» характерны для европейской культуры после Великой французской революции и последовавших националистических движений (особенно в период наполеоновских войн), но никак не применимы к Персии. Говоря о турках, Петр Бестужев противопоставляет их персам, говоря об их воинственности и о том, что турки более свободолюбивы, поскольку могут восстать против деспота, нарушающего закон. «Для них не чуждо слово: отечество!» - пишет он (Бестужев, 1951, с. 352). Очевидно восприятие турецкой истории через призму европейской либеральной традиции, укорененность в которой Петра Бесту- 
жева несомненна. К слову, стоит понимать, что Кавказ являлся фронтиром не только для Российской империи, но и для Персии, Османской империи.

Петр Бестужев говорит о грубости и рабстве турок, персов, но отмечает, что персы более восприимчивы к европейскому влиянию, потому, с одной стороны, менее грубы в обычной жизни, чем турки, но в то же время они «заняли у иностранцев бесчувственность ко всему родному» (Бестужев, 1951, c. 353). При описании персов и турок Петр Бестужев выделяет две тенденции, характерные для европейской культуры той эпохи: с одной стороны, просвещенческий космополитизл, стремление перенимать образ жизни передовых народов ради общечеловеческого прогресса, с другой - романтический национализл, утверждающий самоценность народного духа, культурного своеобразия. Рассуждая о восточных нравах, Петр Бестужев по сути говорит не о Востоке, а о европейских проблемах.

Он говорит о том, что для того, чтобы проникнуться красотой восточной природы и культуры, нужно сменить привычную европейскую оптику:

«Не сбросив с себя европейства у ворот карантина, не закружив мысли обаянием природы, не понимая языка песен, Вы будете мертвец среди кипения жизни. Я не был им. Плавкая природа моя на время переливается во все формы, принимает цвет окружающих ее предметов; забывает мысль и думу на груди природы, как забывает иногда тело и мир на газовых крыльях думы» (БестужевМарлинский, 1995e, с. 532).

В сущности, это превращение представляет собой едва ли не главное экзистенциальное переживание фронтира.

Бестужев-Марлинский рассуждает на важнейшую для той эпохи тему о сопряжении всемирного и национального. Прогресс человечества, с его точки зрения, осуществляется частью народов, которые тянут из варварства всех прочих, увеличивая массу благоденствия. Но эта идея вовсе не отменяет долга перед своим отечеством, поскольку счастье человечества относится к будущему, а в настоящем есть борьба народностей за самосохранение:

«Но все это лишь в отношении к будущему, которое не должно и не может уничтожать настоящих обязанностей человека. И вот почему я был горячим ненавистником немецкого космополитизма, убивающего всякое благородное чувство отечественности, народности. "Lassen sie es gehen und untergehen" прелестное правило: оно во сто раз хуже турецкого фатализма! Мы видели, до какого унижения довело это бесстрастие Германию во время Наполеона!!» (Бестужев-Марлинский, 1995h, с. 497).

На самом деле космополитизм германской мысли рубежа веков также по большей части не противоречил патриотическим и националистическим чувствам, но согласовывался с ними в представлении об отдаленной цели единения человечества (например, «вечный мир» И. Канта), к которой народы движутся через борьбу друг с другом, через войны, которые служат улучшению нравов. Вероятно, такие взгляды были близки и Марлинскому. 
Journal of Frontier Studies. 2022. No 1 | ISSN: 2500-0225

Empire in a Personal Dimension | https://doi.org/10.46539/jfs.v7i1.382

\section{Мятежники против мятежников. Правда войны и смысл империи}

Марлинский не единожды обращался к событиям наполеоновских войн через призму фронтирного опыта. Например, он писал, что слава Дениса Давыдова в большей степени зиждется на его литературном таланте, нежели на воинских успехах. С его точки зрения, отступающие французы, против которых действовал Давыдов, были намного менее опасным противником, чем горцы, которые всегда готовы вступить в бой с многократно превосходящим противником (Бестужев-Марлинский, 1995f, с. 516). Горцы в принципе пользуются у Марлинского особым уважением, и он высоко ценит их как воинов: «Я недавно возвратился из похода в горы. Был не раз в делах и скажу Вам, что горцы достойные дети Кавказа... Это не персияне, не турки» (БестужевМарлинский, 1995i, с. 509). Действительно, Кавказская война принципиально отличалась от европейских войн еще и тем, что врагов не всегда было легко идентифицировать. Отсутствие единой формы, отличающей вражескую армию, делало каждого горца потенциально опасным, а отсутствие европейской дипломатии отдавало вражду и мир в сферу илплищитной лояльности или враждебности того или иного селения русским властям.

Марлинский довольно отчетливо дифференцирует горцев на «своих» и «чужих». Понятно, что демаркация здесь проходит по линии лояльности российскому государю и отечеству, «своими» выступают те, кто в составе туземных частей, вместе с казаками и регулярными войсками действует против взбунтовавшихся «чужих» горцев: «Аскер-Али-бек и командующие мусульманскими полками, майор Мещеряков и гвардии штабс-капитан Юферов, втоптали неприятеля в ущелье, по которому вилась дорога к Чиркею» (Бестужев-Марлинский, 1995d, с. 114). Для обозначения «своих» Марлинский использует слово «мусульмане», хвалит их за храбрость:

«С убитыми и ранеными потеряли мы в этом деле четырех офицеров и до девяноста нижних чинов, включая в то число и мусульман, дравшихся отлично» (Бестужев-Марлинский, 1995d, с. 108). Интересно также, что обычно он не называет лояльных горцев «азиатцами»: «Куда не жалуют азиатцы гранат! В это время наши мусульманские удальцы стали доезжать до самых завалов» (БестужевМарлинский, 1995d, с. 112).

Описывая оборону Дербента, Марлинский повествует, как мусульмане (жители города) соревнуются в удали с русским гарнизоном. Как уже говорилось, разница между своими и чужими определяется степенью лояльности Российскому государству, а одной из главных черт «азиатцев» Марлинский называет доверчивость, детскую наивность, делающую их склонными к мятежу. Вот как описывает он процесс вовлечения горцев в восстание устроенное Кази-Муллой: 
«Каждый день, под предлогом шариата, то есть толкования Корана, проповедовал он ненависть к русским и независимость от всех властей. Воззвания его, исполненные блестящих парадоксов, летели как искры во все стороны и зажигали соломенные умы горцев» (Бестужев-Марлинский, 1995d, с. 106).

Мусульманское духовенство весьма подозрительно смотрело на распространение русского влияния (особенно светского образования), справедливо видя здесь отчетливую тенденцию к ассимиляции, потрясающую традиционные религиозные основы общества (Хлынина и др., 2012, с. 51).

Упоительное описание войны, характерное для Марлинского, контрастно сменяется гуманистическими переживаниями и рассуждениями о ее ужасах. Эти размышления приходят, например, после тяжелых боев, бессонницы и ночи, проведенной в секрете:

«На меня нашел какой-то жалобный стих... Свист ядер с большой батареи слышался мне стоном вдов и сирот. “Для чего люди терзают друг друга беспощадно?" - подумал я... но не успел додумать: я заснул богатырским сном...» (Бестужев-Марлинский, 1995d, с. 119).

Общегуманистические постулаты звучат у Марлинского в разговоре с одним из горцев, которых принудили к сдаче. Необходимость войны обосновывается защитой окрестных жителей от мятежника Кази-Муллы и горцу внушается мысль о неизбежной победе русских:

«- Нет, приятель! Русские не отступают без удовлетворения. Вы видите, что нельзя перелететь за реку! Вы видели, что мы едва-едва не перешли за нее. Простоим еще неделю, месяц, и построим мост, запрудим Сулак ваш, и хоть потеряем половину солдат, а непременно возьмем Чиркей. Тогда не ждите пощады.

Горец нахмурился и молчал; другие сердито шептались между собою. Я продолжал:

- Вы славно дрались, а бой не проходит даром. Я чай, много у вас ранено, убито?

Лица горцев померкли вдруг, будто тяжелою мыслью: иные потупили очи, иные отворотились.

- Не спрашивай нас об этом... - отвечали они. - На жизнь и смерть Божия воля» (Бестужев-Марлинский, 1995d, с. 122).

Марлинский исповедует экспансионистские взгляды. Война для него естественна, неизбежна при соприкосновении с Азией. Мысль о том, что, в отличие от европейца, с которым можно договариваться через взаимные уступки, азиат понимает только силу и любой компромисс воспринимает как слабость, повторяется у него несколько раз (Бестужев-Марлинский, 1995а, c. 43). «Для азиатца нет другой узды, кроме мести. Доброту он считает слабостию, да едва ли мы не были с ними и вправду слабы», - пишет он (БестужевМарлинский, 1995l, с. 500). Жестокость абсолютно необходима с его точки зрения, поскольку, в сущности, только через это можно сохранить мир и уберечь русских солдат и мусульман от еще большего кровопролития. 
Примечательно, что Петр Бестужев, тяготившийся службой и уволенный в итоге из-за психического расстройства, оказывается при описании турецкой кампании едва ли не воинственнее, чем брат Александр:

«Ежели бог войны не удержит губительную свою десницу в Европе, пойдем на Арзрум, будем пить целительную воду в источниках Евфрат а и, может быть, купаться в банях калифов багдадских...» (Бестужев, 1951, с. 348).

Имперское мессианство ему не чуждо. Вот что он пишет в воспоминаниях о штурме крепости Ахалцих, где был ранен:

\begin{abstract}
«Замечательно, что во время блокады города над минаретом прекрасной мечети, построенной, как уверяют, по плану Софийской в Константинополе, лопнула бомба и сбила луну, его увенчивающую. Плохое предсказание для ее обожателей... Душевно желаю, чтоб победители за Варною совершили то же над подлинником... Тогда... глухо раздастся в целой Европе звук молотов, - от ковки креста, от святой Софии, - и воспрянут утомленные неравною борьбою потомки Периклов и Сократов...» (Бестужев, 1951, с. 349).
\end{abstract}

Джерсильд обращает внимание на темы наследия Византии и освобождения христиан в русском имперском сознании, но у него речь идет о славянофильстве (Jersild, 2002, с. 39). Записки Петра Бестужева появились раньше. Примечательно, как декабрист предвосхищает многие интенции русских консерваторов.

Александр Бестужев-Марлинский, несмотря на всю свою воинственность, конечно, не сторонник тактики выжженной земли: «Густела ночь, когда мы начали отступать. Г. Панкратьев не велел предавать Эрпилей пламени, по просьбе шамхала, предвидя, что эта милость обратит эрпилинцев на сторону русских, - и не ошибся» (Бестужев-Марлинский, 1995d, с. 113). Генерал Панкратьев в этом отношении поступает мудро, давая противнику возможность сдаться без лишнего кровопролития и не вызывая непреодолимого ожесточения со стороны горцев. Условиями для горцев становятся признание власти русского императора, отказ от помощи мятежникам и возврат захваченного орудия. Таким образом, восстановление государственной монополии на насилие, по сути, является основным условием прекращения кровопролития. При этом Марлинский акцентирует внимание на том, что генерал Панкратьев помиловал горцев именем государя императора: «где краше имя царское, как не в помиловании» (Бестужев-Марлинский, 1995d, c. 110).

Бестужев-Марлинский в своих военных записках довольно часто демонстрирует лояльность Николаю I: «Но всего более восхищало нас, что в тот день, в который радостная Россия возложила венок Мономаха на голову достойнейшего из царей, победа свила новый венок на его оружие!» (Бестужев-Марлинский, 1995d, c. 132). Описываемый дагестанский поход предстает у Марлинского как одно из значительных событий царствования императора (Бестужев-Марлинский, 1995d, с. 128). Все победы представляются именно 
как победы русского царя над силами природы, где местные жители оказываются частью покоряемого ландшафта:

«Итак, в один день совершено покорение одного из неприступнейших селений Кавказа, которое оградил он в лоне своем и крутью гор и быстрым потоком! Люди, не признававшие от века никаких властей, склонились пред оружием русского царя. Что ж может противостать его воле, уму его вождей, отваге его воинов, когда здесь самую природу победили силы человека!» (Бестужев-Марлинский, 1995d, с. 121).

Император Николай I впервые посетил Кавказ в 1837 году, через несколько месяцев после гибели в ходе десантной операции на мысе Адлер прапорщика Александра Александровича Бестужева-Марлинского.

\section{Чужая земля}

«Все кинули по горсти земли, чужой земли, на очи собратий...

"Sit uobis terra levis

[да будет легка над вами земля]", - сказал я про себя»

(Бестужев-Марлинский, 1995d, с. 108).

Часто природа Кавказа представляется у Марлинского как союзник враждебных горцев, предоставляя им естественные фортификационные возможности и создавая враждебный завоевателям ландшафт. Природа и люди являются у него в единстве объекта приложения усилий: «Туман клубился из оврагов, будто рвов, изрытых природою в оборону этому гнезду храбрых разбойников, стекшихся из Чечни и салатавских деревень на помощь ближним. Первый луч солнца, сверкнувший на теме Кавказа, казалось, зажег снова огонь вражды и громы пушек» (Бестужев-Марлинский, 1995d, с. 118). Природа становится как бы еще более величественной и грозной от человеческой вражды. Именно расширение господства над природой двигает американцами при освоении фронтирных земель с точки зрения Тернера (Тернер, 2009, с. 17).

Русская армия действовала не только против людей, но и против природы. «Ни помощь природы, ни силы огражденного неприступностью человека не устояли перед храбростью русских...», - пишет Марлинский (Бестужев-Марлинский, 1995d, с. 128). Покорение Кавказа сопровождалось радикальным преобразованием ландшафта, прежде всего - рубкой леса. Европейская армия, привыкшая воевать в боевых порядках, где штык является основным оружием, использовать артиллерию, нуждалась в открытом пространстве. На значительных площадях удалось вырубить лес, оставив горцев без укрытий и жизненно важной древесины, что, естественно, способствовало их враждебности. Ландшафт Дагестана, где много времени провел и 
Марлинский, весьма угнетающе воздействовал на русских солдат и офицеров. Именно здесь ощущение чужой земли должно было быть наиболее острым.

Фронтирные территории Российской империи в XIX веке не назывались Россией. Кавказ, разумеется, тоже не воспринимается как часть России: «Он уехал на Минеральные Воды и оттуда в благословенную Россию...», - замечает Петр Бестужев в одном из писем (Бестужев, 1951, с. 342). Между тем, Марлинский все же воспринимает Кавказ частью Отечества: «Любопытна теперь западная сторона нашего отечества, любезнейшая матушка, но в малом размере не менее занимателен и Кавказ, восточный бок русского великана» (Бестужев-Марлинский, 19951, с. 500). Кавказ еще предстояло сделать органичной частью Российской империи, а пока он был, с одной стороны, местом изгнания, а с другой стороны, как и всякая фронтирная территория, местол возможностей. Для одних - просто возможности продвижения по службе, для других - единственный способ вернуть прежний социальный статус. По этой причине русские не избегали столкновений, а зачастую сами искали их. Бестужев-Марлинский красочно описывает бои и победы, но при этом ощущение изгнания, очевидно, не покидает его: «Не только башен Кремля, столь горячо любимых мною, - не видать мне и снегов родины, снегов, за горсть коих отдал бы я весь виноград Кавказа, все розы Адербиджана - у них одни шипы для изгнанника» (Бестужев-Марлинский, 1995j, с. 523).

Стоит отметить и обратное влияние кавказского ландшафта, образа жизни на людей, волею судьбы оказавшихся на кавказском фронтире: «На поднебесном Кавказе, кажется, нельзя не возвыситься духом», - пишет Марлинский (Бестужев-Марлинский, 1981d, с. 494). В его эстетических и историософских построениях ландшафт и климат играет важнейшую, если не решающую роль в форлировании народного духа и народной культуры. С точки зрения писателя, отличительными чертами кавказцев (как и скандинавов) является гордость, свобода и бесстрашие, обусловленные бедностью, вызванной климатом не слишком суровым, но и не слишком благоприятным, а именно таким, где рассчитывать приходится исключительно на свои силы. Поэтому кавказским народам свойственен индивидуализм: «послушайте песен аварца или черкеса: это вечная вариация местоимений я или мы; а "мы” значило у них мой род, моя деревня, моя дружина» (Бестужев-Марлинский, 1991, с. 140). Этот специфический кавказский гипериндивидуализм (характерный и для американского фронтира) хорошо резонирует, с одной стороны, поэтике изгнания, свойственной Марлинскому и Лермонтову, а с другой стороны формированию специфической социальной группы офицеров-кавказцев со своей идентичностью (Хлынина и др., 2012, с. 64).

Примечательно, что как раз в период службы на Кавказе Марлинского и Лермонтова среди горцев стал с невероятной силой распространяться мюридизм - направление в суфийском исламе, характеризующееся жестким фата-

1 См. подробно: (Вартумян , Берберова, 2014). 
лизмом и детерминизмом. Марлинский воевал против главного проповедника мюридизма Гази-Мухаммада (Кази-Мулла), Лермонтов «замирял» его ученика Шамиля. Фатализм Лермонтова часто относят к ориентальным мотивам его творчества и небезосновательно связывают с восточным влиянием (Алексеев, 2013). Вероятно, это справедливо и в отношении Марлинского. О всевластности судьбы постоянно говорят персонажи писателя и сам Марлинский - в военных записках:

«Судьба уже отмечала лица жертв железным перстом своим. Скажите, какая нить связывает два мира, две судьбы, две жизни? Скажите, отчего, готовясь расторгнуться, она почти всегда дает ощутить себя то грустью предчувствия, то зловещими снами?» (Бестужев-Марлинский, 1995d, с. 125).

Сам Марлинский выступает резко против фатализма, который, по его мнению, противоречит христианской этике и уничтожает всякую активность личности (Бестужев-Марлинский, 1995b, с. 343). Когда речь об этом заходит напрямую, он декларирует радикальный индетерминизм. Вероятно, Марлинский боролся не только с судьбой, но и с собственным фатализмом. Получив известие о смерти Пушкина, он пишет, что тут же заказал на могиле Грибоедова панихиду «за убиенных боляр Александра и Александра». Он пророчит собственную смерть: «Да, я чувствую, что моя смерть также будет насильственной и необычайной, что она уже недалеко» (БестужевМарлинский, 1995m, с. 544). Через несколько месяцев, находясь на фрегате «Анна», стоящем против мыса Адлер, писатель сделает последние распоряжения (Бестужев-Марлинский, 1995с, с. 545) о своем имуществе и погибнет в тот же день.

\section{Заключение}

Бестужев-Марлинский был одним из тех, кто открыл Кавказ для русской культуры, в определенный момент он стал главным бытописателем южного фронтира для широкой публики. Его можно было бы обвинить в представлении Кавказа через аберрации романтической оптики, но дело в том, что одной из характерных черт романтической культуры являлось требование соответствия образа творца и его произведения. Жизнетворчество было частью создаваемого искусства. В этом смысле Бестужев-Марлинский как истинный романтик жил той жизнью, о которой писал.

Его мировоззрение отличалось двойственностью. Там нашлось место декабризму, лояльности императору, интересу к Востоку и русскому колониализму, упоению битвами и тягостному описанию жестокостей войны. При этом лояльность империи и имперскому принципу в мировоззрении Бестужева составляла неизменный субстрат.

Русское мессианство было связано для братьев Бестужевых с идеей распространения христианства через Россию как подлинно христианскую 
империю. Европейские просвещенческие идеи, предполагавшие экспансию цивилизации на дикие края, романтические историософские построения служили идейным основанием интенций Российской Империи в сторону Кавказа. Джерсильд пишет: «Многие русские понимали экспансию как часть исторической кампании по оттеснению границ мусульманской "дикости" с земель христианского мира» (Jersild, 2002, с. 16). Символично в этом отношении, что в результате десантной операции, при которой погиб БестужевМарлинский, возникло фортификационное сооружение - крепость Святого Духа ${ }^{1}$.

Колониализм был неотъемлемой частью мировоззрения Марлинского. Движение Европы в Азию и победа Европы, с его точки зрения, неизбежны. Кавказ должен был быть покорен во славу Империи и стать частью России, несмотря на жертвы. Твердый имперский порядок, по его мысли единственный залог мира. Имперский этатизм связан у братьев Бестужевых с почитанием фигуры Петра I как демиурга русского государства, утвердившего его в качестве европейской империи. Как указывает Джерсильд, русские воспринимали себя как носители европейской цивилизации, что давало российской экспансии аналогичный Западному колониальный импульс.

Европоцентризм Бестужева не вызывает сомнения. Европа, христианство и цивилизация были понятиями почти синонимичными для людей его эпохи, но при этом примечательна интенция Марлинского выйти за пределы европейской оптики при соприкосновении с культурой Востока.

Фронтир как граница, территория соприкосновения противоположных явлений, где происходит их взаимовлияние, пролег через судьбу и творчество Александра Бестужева-Марлинского. Эпохи Просвещения и романтизма, мятежность и лояльность, восточный фатализм и идеал христианской внутренней свободы составляли полюса его мировоззрения. Он жил на границе эпох и культурных парадигм. И погиб на границе цивилизаций.

\section{Благодарности}

Исследование выполнено за счет гранта Российского научного фонда, проект № 21-18-00153 «Идея империи и идея революции: два полюса русского общественно-политического мировоззрения в философии и культуре XIX-XXI веков».

1 В 2020 году в честь этих событий на месте, где располагалась крепость, в Сочи был установлен памятник. И вскоре снесен. Установка и снос этого памятника вызвали широкий общественный резонанс, что еще раз подтверждает, что старинные сюжеты кавказской войны могут неожиданно актуализироваться. 


\section{Список литературы}

Jersild, O. (2002). Orientalism and Empire: North Caucasus Mountain People and the Georgian Frontier, 1845-1917. McGill-Queen's University Press.

Алексеев, П. В. (2013). Восточный текст в поэтике М.Ю. Лермонтова. Вестник Томского государственного университета, 374, 7-10.

Андреева, Т. В. (2021). Эпоха Петра I в историческом сознании декабристов. Вестник Новосибирского государственного университета. Серия: История, филология, 20(1), 71-81. https://doi.org/10.25205/1818-7919-2021-20-1-71-81

Баева, Л. В. (2014). Типология и проблемы изучения Южно-российского фронтира. Вестник Волгоградского государственного университета. Серия 7: Философия. Сощиология и Социальные технологии, 2, 32-38.

Барретт, Т. М. (2000). Линии неопределенности: Северокавказский «фронтир» России. В Алериканская русистика: Вехи историографии последних лет. Илператорский период (сс. 163-195). б. и.

Бестужев-Марлинский, А. А. (1981a). Взгляд на русскую словесность в течение 1823 года. В Бестужев-Марлинский А. А. Сочинения в 2 томах (Т. 2, сс. 394-400). Художественная литература.

Бестужев-Марлинский, А. А. (1981b). Взгляд на русскую словесность в течение 1824 и начале 1825 года. В Бестужев-Марлинский А. А. Сочинения в 2 томах (Т. 2, сс. 401-411). Художественная литература.

Бестужев-Марлинский, А. А. (1981с). Об историческом ходе свободомыслия в России (письмо Николаю I). В Бестужев-Марлинский А. А. Сочинения в 2 томах (Т. 2, сс. 485-493). Художественная литература.

Бестужев-Марлинский, А. А. (1981d). Письмо А. А. Бестужева-Марлинского П. А. Бестужеву 10 апреля 1828. В Бестужев-Марлинский А. А. Сочинения в 2 томах (Т. 2, сс. 493-494). Художественная литература.

Бестужев-Марлинский, А. А. (1991). О романе Н. Полевого «Клятва при гробе Господнем». В Декабристы: Эстетика и критика (сс. 133-187). Искусство.

Бестужев-Марлинский, А. А. (1995а). Аммалат-бек. В Кавказские повести (сс. 5-93). Наука.

Бестужев-Марлинский, А. А. (1995b). Вадимов. В Кавказские повести (сс. 318-348). Наука.

Бестужев-Марлинский, А. А. (1995с). Духовное завещание Бестужева 7 июня 1837. В Кавказские повести (с. 545). Наука.

Бестужев-Марлинский, А. А. (1995d). Письма из Дагестана. В Кавказские повести (сс. 94-132). Наука.

Бестужев-Марлинский, А. А. (1995е). Письмо А. А. Бестужева-Марлинского К. А. Полевому 31 мая 1834. В Кавказские повести (сс. 533-534). Наука.

Бестужев-Марлинский, А. А. (1995f). Письмо А. А. Бестужева-Марлинского К. А. Полевому 15 марта 1832. В Кавказские повести (сс. 516-517). Наука.

Бестужев-Марлинский, А. А. (1995g). Письмо А. А. Бестужева-Марлинского Н. А. и М. А. Бестужевым, 15 января 1833. В Кавказские повести (сс. 519-520). Наука. 
Бестужев-Марлинский, А. А. (1995h). Письмо А. А. Бестужева-Марлинского Н. А. Полевому 23 апреля 1831. В Кавказские повести (сс. 497-498). Наука.

Бестужев-Марлинский, А. А. (1995i). Письмо А. А. Бестужева-Марлинского Н. А. и К. А. Полевым 16 декабря 1831. В Кавказские повести (сс. 506-511). Наука.

Бестужев-Марлинский, А. А. (1995j). Письмо А. А. Бестужева-Марлинского Н. А. Полевому 9 марта 1833. В Кавказские повести (сс. 523-524). Наука.

Бестужев-Марлинский, А. А. (1995k). Письмо А. А. Бестужева-Марлинского П. М., Е. А., О. Л. И М. А. Бестужевым, 24 декабря 1830. В Кавказские повести (сс. 490-491). Наука.

Бестужев-Марлинский, А. А. (1995l). Письмо А. А. Бестужева-Марлинского П. М. Бестужевой июнь 1831. В Кавказские повести (сс. 500-502). Наука.

Бестужев-Марлинский, А. А. (1995m). Письмо А. А. Бестужева-Марлинского П. А. Бестужеву 23 февраля 1837. В Кавказские повести (сс. 543-545). Наука.

Бестужев-Марлинский, А. А. (1995n). Следствие вечера на кавказских водах. В Кавказские повести (сс. 173-179). Наука.

Бестужев, П. А. (1951). Памятные записки. 1828 и 1829 годы. В Восполинания Бестужевых. Издательство АН СССР.

Валицкий, А. (2013). История русской мысли от просвещения до марксизма. Канон+.

Вартумян, А. А., \& Берберова, Е. Г. (2014). Северокавказский фронтир как объект изучения политической географии. Современная наука и инноващии, 4, 164-173.

Койре, А. (2003). Философия и национальная проблема в России начала ХІХ века. МОДЕСТ КОЛЕРОВ.

Муравьев, Н. М. (1951). Проект Конституции. В Избранные социально-политические и философские произведения декабристов в 3 томах (Т. 1, сс. 295-329). Государственное издательство политической литературы.

Пестель, П. И. (1958). Русская правда. В Восстание декабристов. Документы (Т. 1, сс. 113-218). ГОСПОЛИТИЗДАТ.

Романова, А. П., \& Ермуханова, Н. А. (2015). Межкультурные коммуникации на этапе раннего фронтира на Кавказе. Исторические, философские, политические и юридические науки, культурология и искусствоведение. Вопросы теории и практики, 1-1, 172-175.

Синельникова, Л. Н. (2020). Концептуальная среда фронтирного дискурса в гуманитарных науках. Russian Journal of Linguistics, 24(2), 467-492. https://doi.org/10.22363/2687-0088$\underline{2020-24-2-467-492}$

Следственное дело А. А. Бестужева (Марлинского). (1925). В Восстание декабристов. Материалы (Т. 1, сс. 425-473). Государственное издательство.

Смирнов, В. Н., \& Евлампиев, И. И. (2020). Система Гегеля и Романтизм: Два полюса исторических воззрений П. Я. Чаадаева. Вестник Русской христианской гуманитарной академии, 21(4-2), 124-136.

Тёрнер, Ф. Дж. (2009). Фронтир в американской истории. Весь Мир.

Толстой, Л. Н. (1979). Набег. В Л. Н. Толстой, Собрание сочинений в 22 томах (Т. 2, сс. 7-32). Художественная литература. 
Хлынина, Т. П., Кринко, Е. Ф., \& Урушадзе, А. Т. (2012). Российский Северный Кавказ: Исторический опыт управления и формирования грании региона. Южный научный центр РАН.

Ходарковский, М. (2016). Горький выбор. Верность и предательство в эпоху российского завоевания Северного Кавказа. Новое литературное обозрение.

\section{References}

Alekseev, P. V. (2013). The Eastern Text in the Poetics of Mikhail Lermontov. Bulletin of Tomsk State University, 374, 7-10. (In Russian).

Andreeva, T. V. (2021). The Age of Peter the Great in the Historical Consciousness of the Decembrists. Vestnik of Novosibirsk State University. Series: History, Philology, 20(1), 71-81. https://doi.org/10.25205/1818-7919-2021-20-1-71-81 (In Russian).

Baeva, L. V. (2014). Typology and Problems of Studying the Southern Russian Frontier. Bulletin of Volgograd State University. Series 7: Philosophy. Sociology and Social Technologies, 2, 32-38. (In Russian).

Barrett, T. M. (2000). Lines of Uncertainty: Russia's North Caucasus Frontier. In American Russian Studies: Milestones in Historiography in Recent Years. The Imperial Period (pp. 163-195). n. p. (In Russian).

Bestuzhev-Marlinsky, A. A. (1981a). A look at Russian literature during 1823. In Bestuzhev-Marlinsky A. A. Works in 2 volumes (Vol. 2, pp. 394-400). Khudozhestvennaja literatura. (In Russian).

Bestuzhev-Marlinsky, A. A. (1981b). A look at Russian literature during 1824 and early 1825. In Bestuzhev-Marlinsky A. A. Works in 2 volumes (Vol. 2, pp. 401-411). Khudozhestvennaja literatura. (In Russian).

Bestuzhev-Marlinsky, A. A. (1981c). On the historical course of freethinking in Russia (letter to Nicholas I). In Bestuzhev-Marlinsky A. A. Works in 2 volumes (Vol. 2, pp. 485-493). Khudozhestvennaja literatura. (In Russian).

Bestuzhev-Marlinsky, A. A. (1981d). Letter from A. A. Bestuzhev-Marlinsky to P. A. Bestuzhev on 10 April 1828. In Bestuzhev-Marlinsky A. A. Works in 2 volumes (Vol. 2, pp. 493-494). Khudozhestvennaja literatura. (In Russian).

Bestuzhev-Marlinsky, А. А. (1991). О романе Н. Полевого «Клятва при гробе Господнем». In Декабристы: Эстетика и критика (pp. 133-187). Искусство. (In Russian).

Bestuzhev-Marlinsky, A. A. (1995a). Ammalat-bek. In Caucasian Novels (pp. 5-93). Nauka. (In Russian).

Bestuzhev-Marlinsky, A. A. (1995b). Vadimov. In Caucasian Novels (pp. 318-348). Nauka.

Bestuzhev-Marlinsky, A. A. (1995c). Bestuzhev's last will and testament 7 June 1837. In Caucasian Novels (c. 545). Nauka. (In Russian).

Bestuzhev-Marlinsky, A. A. (1995d). Letters from Dagestan. In Caucasian Novels (pp. 94-132). Nauka. (In Russian).

Bestuzhev-Marlinsky, A. A. (1995e). Letter from A.A. Bestuzhev-Marlinsky to K.A. Polevoj on 31 May 1834. In Caucasian Novels (pp. 533-534). Nauka. (In Russian).

Bestuzhev-Marlinsky, A. A. (1995f). Letter from A.A. Bestuzhev-Marlinsky to K.A. Polevoj on 15 March 1832. In Caucasian Novels (pp. 516-517). Nauka. (In Russian). 
Bestuzhev-Marlinsky, A. A. (1995g). Letter from A. A. Bestuzhev-Marlinsky to N. A. and M. A. Bestuzhev, 15 January 1833. In Caucasian Novels (pp. 519-520). Nauka.

Bestuzhev-Marlinsky, A. A. (1995h). Letter from A. A. Bestuzhev-Marlinsky to N. A. Polevoj on 23 April 1831. B Caucasian Novels (pp. 497-498). Nauka.

Bestuzhev-Marlinsky, A. A. (1995i). Letter from A. A. Bestuzhev-Marlinsky to N. A. and K. A. Polevoy on 16 December 1831. In Caucasian Novels (pp. 506-511). Nauka. (In Russian).

Bestuzhev-Marlinsky, A. A. (1995j). Letter from A. A. Bestuzhev-Marlinsky to N. A. Polevoj on 9 March 1833. In Caucasian Novels (pp. 523-524). Nauka. (In Russian).

Bestuzhev-Marlinsky, A. A. (1995k). Letter from A. A. Bestuzhev-Marlinsky to P. M., E. A., O. L. and M. A. Bestuzhev, 24 December 1830. In Caucasian Novels (pp. 490-491). Nauka. (In Russian).

Bestuzhev-Marlinsky, A. A. (1995l). Letter from A.A. Bestuzhev-Marlinsky to P.M. Bestuzheva June 1831. In Caucasian Novels (pp. 500-502). Nauka. (In Russian).

Bestuzhev-Marlinsky, A. A. (1995m). Letter from A. A. Bestuzhev-Marlinsky to P. A. Bestuzhev on 23 February 1837. In Caucasian Novels (pp. 543-545). Nauka. (In Russian).

Bestuzhev-Marlinsky, A. A. (1995n). Investigation of an evening at the Caucasus Waters. In Caucasian Novels (pp. 173-179). Nauka. (In Russian).

Bestuzhev, P. A. (1951). Memoirs. 1828 and 1829. In Memories of the Bestuzhevs. USSR Academy of Sciences Publishing. (In Russian).

Investigation file of A. A. Bestuzhev (Marlinsky). (1925). In Decembrist Uprising. Materials (T. 1, pp. 425-473). State publishing house. (In Russian).

Jersild, O. (2002). Orientalism and Empire: North Caucasus Mountain People and the Georgian Frontier, 1845-1917. McGill-Queen's University Press.

Khlynina, T. P., Krinko, E. F., \& Urushadze, A. T. (2012). The Russian North Caucasus: A Historical Experience of Governance and Regional Boundary Formation. Southern Scientific Centre of the Russian Academy of Sciences. (In Russian).

Khodarkovsky, M. (2016). A bitter choice. Loyalty and betrayal in the era of the Russian conquest of the North Caucasus. New Literary Review. (In Russian).

Koire, A. (2003). Philosophy and the national problem in early 19th century Russia. MODEST KOLEROV. (In Russian).

Muravyev, N. M. (1951). Draft Constitution. In Selected socio-political and philosophical works of the Decembrists in 3 volumes (Vol. 1, pp. 295-329). State Publishers of Political Literature. (In Russian).

Pestel, P. I. (1958). Russkaya pravda. In Decembrist Uprising. Documents (Vol. 1, pp. 113-218). GOSPOLITIZDAT. (In Russian).

Romanova, A. P., \& Ermukhanova, N. A. (2015). Intercultural Communication in the Early Frontier in the Caucasus. Historical, philosophical, political and legal sciences, cultural studies and art criticism. Theory and practice issues, 1-1, 172-175. (In Russian).

Sinelnikova, L. N. (2020). The Conceptual Environment of Frontier Discourse in the Humanities. Russian Journal of Linguistics, 24(2), 467-492. https://doi.org/10.22363/2687-0088-2020-242-467-492 (In Russian). 
Smirnov, V. N., \& Yevlampiev, I. I. (2020). Hegel's System and Romanticism: Two Poles of P. Ja. Chaadayev's Historical Perspectives. Bulletin of the Russian Christian Academy for the Humanities, 21(4-2), 124-136. (In Russian).

Tolstoy, L. N. (1979). The Raid. In L. N. Tolstoy, Collected Works in 22 volumes (Vol. 2, pp. 7-32). Khudozhestvennaja literatura. (In Russian).

Turner, F.J. (2009). The frontier in American history. Ves Mir. (In Russian).

Valicki, A. (2013). History of Russian thought from Enlightenment to Marxism. Canon+. (In Russian).

Vartumyan, A. A., \& Berberova, E. G. (2014). The North Caucasus Frontier as an Object of Study in Political Geography. Modern science and innovation, 4, 164-173. (In Russian). 